University of Warwick institutional repository: http://go.warwick.ac.uk/wrap This paper is made available online in accordance with publisher policies. Please scroll down to view the document itself. Please refer to the repository record for this item and our policy information available from the repository home page for further information.

To see the final version of this paper please visit the publisher's website. Access to the published version may require a subscription.

Author(s): Penny Roberts

Article Title: Urban conflict and royal authority: popular revolts in sixteenth-century Troyes

Year of publication: 2007

Link to published version: http://dx.doi.org/

10.1017/S0963926807004609

Publisher statement: None 


\title{
Urban conflict and royal authority: popular revolts in sixteenth-century Troyes
}

\author{
PENNY ROBERTS \\ Dept of History, University of Warwick, Coventry, CV4 7AL
}

\begin{abstract}
This paper explores the relative balance between socio-economic grievance and confessional and political division in urban revolts during the period of the French religious wars. More particularly, it focuses on two such incidents in the town of Troyes in Champagne in the summer of 1586 and what they can tell us about the influence of popular discontent on municipal politics and towncrown relations, as well as the impact of civil war, subsistence crisis and increasing taxation on urban communities. The continuity of the traditions of popular revolt are explored alongside the implications for royal authority of the official response to such unrest. Social tensions and economic concerns dominated events in the town, whilst the crown's right and ability to enforce its will continued to be accepted and upheld. Thus, despite the disruption of civil strife, the competing interests of the municipal authorities, the urban populace and the monarchy were able to maintain a delicate equilibrium through the traditional mechanism of negotiation and compromise.
\end{abstract}

During the French religious wars (1562-98), relations between the French crown and the principal towns of the kingdom were simultaneously conciliatory and fraught. On the one hand, the relationship was symbiotic. The king looked to the municipal authorities to preserve law and order and harmonious relations between the faiths within their jurisdiction; the authorities looked to the king for guidance on these issues, as well as protection from the detrimental effects of civil strife. ${ }^{1}$ On the other hand, there was disagreement about certain aspects of royal religious and fiscal policy and their consequences. In particular, as the Catholic League garnered increasing support after Henry of Navarre, leader of the Protestants, became heir to the French throne in 1584, so the crown became more wary of the continuing loyalty of France's urban communities. The adherence of many of the kingdom's towns to the

${ }^{1}$ Cf. H.J. Bernstein, Between Crown and Community: Politics and Civic Culture in SixteenthCentury Poitiers (Ithaca and London, 2004), 16, 'Urban political life in France existed only in constant reference to royal authority', also on this theme, see 270-5. Annette FinleyCroswhite, Henry IV and the Towns: The Pursuit of Legitimacy in French Urban Society, 15891610 (Cambridge, 1999), 5, refers to the traditional 'alliance and dialogue between crown and towns' of the Renaissance monarchy, see also 9 and 184. 
League from the late 1580 s posed a significant challenge to royal power and subsequently to the succession of Henry IV (1589-1610). It is unsurprising, therefore, that historians have tended to link these events with earlier demonstrations of popular discontent. The increasing fiscal pressures of the 1570s and 1580s, during the reign of Henry III (1574-89), exacerbated tense relations between towndwellers and royal tax-collectors resulting in localized unrest. Subsistence crisis heightened the concerns of the lower orders, the menu peuple, erupting in public protest on the streets. Whilst recognizing the traditional motivations of such outbreaks, Denis Crouzet and others have postulated that they fed into the political divisions of the elites between Leaguer and Royalist. ${ }^{2}$ The context of individual towns' experience of revolt during this period can allow us to assess more clearly the relative balance of political and socio-economic factors in the grievances of ordinary urban inhabitants at this time.

The century 1560-1660 has long been recognized as an especially turbulent period for popular unrest in Europe. However, historians of early modern France have tended to treat the major outbreaks, those of the 1580 s to 1590 s and 1630s, in isolation one from another and, as a result, drawn quite separate conclusions about their motivation and organization. In addition, until their systematic study by William Beik, French urban revolts were something of a poor relation to their rural counterparts which have attracted the majority of in-depth studies. ${ }^{3}$ The unrest of the $1580 \mathrm{~s}$ is often portrayed as part of a nationwide discontent with political weakness at the centre, the increased burden of taxation at a time of economic crisis and the need for a strong Catholic reaction in the face of a resurgent Protestantism. In this way, these revolts are seen to have threatened the position of the French monarchy itself, whereas the disturbances of the 1630s, though again a reaction against the fiscal pressure brought to bear by the burden of royal taxation, are seen as more localized and provincially based, and ultimately a failure when confronted by the inexorable drive towards centralization. Of course, the provincial nature of these revolts has long been recognized as a natural and effective means for the participants to achieve their aims, however limited these might now appear. Yet much

2 Denis Crouzet, Les guerriers de dieu. La violence au temps des troubles de religion, vers 1525 -vers 1610, 2 vols. (Paris, 1990), vol. II, 267. As also argued by J.R. Farr, Hands of Honor: Artisans and their World in Dijon, 1550-1650 (Ithaca and London, 1988), 198.

${ }^{3}$ William Beik, Urban Protest in Seventeenth-Century France: The Culture of Retribution (Cambridge, 1997), includes a brief discussion of the events in Troyes in 1586 (54-7), and is a notable exception in addressing the continuity of revolt over the period. Among the few in-depth studies of instances of urban revolt in the period, is E. Le Roy Ladurie, Le carnaval de Romans. De la Chandeleur au mercredi des Cendres, 1579-1580 (Paris, 1979; translated by M. Feeney as Carnival in Romans (New York, 1979)), though it also addresses the rural dimension, see esp. 360. Notably, too, Y.-M. Bercé dealt with urban as well as rural revolts in his monumental Histoire des croquants: étude des soulèvements populaires au XVIIe siècle dans le sud-ouest de la France, 2 vols. (Geneva, 1974), though discussion of these is much reduced in the abridged version of the English translation by A. Whitmore, History of Peasant Revolts: The Social Origins of Rebellion in Early Modern France (Cambridge, 1990); so, too, did René Pillorget in Les mouvements insurrectionnels de Provence entre 1596 et 1715 (Paris, 1975). 
of the unrest of the 1580s (aside from the League revolt itself) was arguably just as conservative and localized, and, faced by such forms of defiance, the crown proved itself to be far from impotent.

One of the main reasons for drawing these chronological distinctions is that sixteenth-century French revolts are usually seen in the context of the religious wars as mere extensions of the divisions caused by the conflict. ${ }^{4}$ Some years ago, Natalie Davis delineated the differences between religious riots and socio-economic revolts, arguing convincingly that they involved different motivations, targets and actions appropriate to the grievance held. ${ }^{5}$ Although this approach appears valid enough for the confessional conflicts of the 1560s and 1570s, the same cannot be said for the revolts at the time of the League, which cannot be so easily extricated from the customary expressions of socio-economic discontent. In addition, the view that they were linked to political intrigue has tended to set them apart from those popular uprisings that came before and after and, therefore, from a tradition of revolt. However, contrary to the thesis that revolts during the latter decades of the wars reflected the growing political tension between the crown and the Catholic League, on closer investigation such unrest appears rather to reveal traditional and localized economic concerns. Recent work has highlighted the importance for town authorities of maintaining popular support as well as the role of popular influence on urban politics through protest. Relations between municipal officials and urban inhabitants were never easy or equally balanced, sometimes proving openly hostile, and always depended on negotiation, especially at times of particular crisis. ${ }^{6}$ Furthermore, the crown's response to popular protest demonstrates its continuing ability to assert its authority in the face of potential disobedience withins its urban communities, despite the disruption caused by civil strife. Such a case can be made by focusing on the unrest which broke out in the streets of the city of Troyes in Champagne in 1586, at the height of the religious wars and just prior to the ascendancy of the League in the town in 1588.

Two separate revolts took place during the classic period of protest, late spring and summer. Subsistence riots often occurred when the effects of a poor harvest and the subsequent high price of foodstuffs were most acutely felt and it became clear that the next harvest promised little better, whilst anti-tax protests shadowed the fiscal calendar, coinciding with the

${ }^{4}$ E.g. P. Zagorin, Rebels and Rulers, 1500-1660, 2 vols. (Cambridge, 1982), vol. I, 236. Henry Heller in Iron and Blood: Civil Wars in Sixteenth-Century France (Montreal and London, 1991), whilst fitting the revolts of the sixteenth century into a continuum with those of the fourteenth and seventeenth centuries, takes a determinist approach to the relationship between popular protest and the religious wars.

5 N.Z. Davis, Society and Culture in Early Modern France (Stanford and London, 1975), ch. 6, 'The rites of violence', also in Past and Present, 59 (1973); and 'Debate: the rites of violence: religious riot in sixteenth-century France: a rejoinder', Past and Present, 67 (1975), esp. 131-2, in response to Janine Garrisson's criticism of her approach in the same volume, 127-30.

${ }^{6}$ Beik, Urban Protest, 1, refers to these negotiations as 'dialogues of power', see also 13, 48, 95; Bernstein, Between Crown and Community, 15, 103-6, 191. 
distribution of warrants and the drawing up of assessment rolls. ${ }^{7}$ Both of these inflammatory elements, subsistence crisis and high taxation, were present to ignite revolt in Troyes in 1586. Much can be gleaned from such incidents regarding the nature of relations and, indeed, tensions between municipal and royal authorities in sixteenth-century France, as well as the attitudes of both these bodies to the actions of discontented urban journeymen at a time of socio-economic difficulty, religious upheaval and monarchical crisis. The royal response to the unrest suggests that the lessons of the civil wars for the crown extended beyond the more obvious political and religious sphere to embrace practical and effective ways in which provincial, and specifically urban, privileges could be eroded in the interests of strengthening royal authority, a trend more usually associated with royal policy towards the towns in the seventeenth century. ${ }^{8}$ But before considering this wider picture, it is necessary to examine briefly the events of the summer of 1586 in Troyes, as well as assessing their causes, their implications and finally the royal reaction to the unrest.

The first and most serious of the protests began on Sunday 29 June, the feast of saints Peter and Paul, to whom the city cathedral is dedicated and which may therefore have been an annual local holiday, although the records do not mention the feasting and other revelry which would have taken place on such an occasion, and which preceded so many outbreaks of popular discontent. The coincidence is nonetheless worth noting. A wealthy merchant and alderman (échevin) Nicolas Dare, our main source for the revolts and one of those charged with the responsibility of suppressing them, terms it rather enigmatically as 'a dangerous day', but this may simply refer to the events which ensued. ${ }^{9}$ The principal targets of the protestors were two royal commissioners accompanied by their bailiffs (huissiers) and sergeants, who had recently arrived in Troyes to enforce the payment of a levy from certain crafts which represented the cost of two supernumerary masterships, valued at 24 écus, granted by Henry III as a gift to his sister some years before. ${ }^{10}$ It appears that the commissioners had given the crafts only two days in which to come up with the money, and 500 craftsmen had been charged to meet the demand. If there was

7 Bercé, Histoire des Croquants, vol. II, 538-48 and 563-6, on the typology of revolt.

${ }^{8}$ Finley-Croswhite, Henry IV and the Towns, argues against a deliberate royal policy to destroy urban privileges, but rather a need to balance and negotiate royal authority and urban autonomy, see esp. 1, 5, 182-6.

${ }^{9}$ It is fortunate that Dare in his position as échevin was able to report fully on the revolt in his memoirs: Mémoires et livre de famille de Nicolas Dare, ed. B. de Barberey and R. de St-Mauris in Collection de documents inédits relatifs à la ville de Troyes et à la Champagne méridionale publiés par la Société académique de l'Aube, vol. III (Troyes, 1886) (hereafter Dare), 50 , 'ung jour dangereux'. The two revolts are covered in detail in the memoirs, 49-62. Beik, Urban Protest, emphasizes rather that it was Sunday, 'a day of rest when they were free to confer and organize', 54 .

10 The original royal demand is found in Actes royaux, jan.-mars 1580, Bibliothèque Nationale, Paris (hereafter BN) Imprimés, F 46864, no. 1, 'Edict de la creation de deux maistrises en chacun mestier, qui seront receuz sans chef-d'oeuvre, en faveur de la royne de Navarre'. 
any further delay, they threatened, then each of the crafts would be charged a further 8 écus to cover the expense of prolonging their stay. ${ }^{11}$ The provocative nature of this approach is clear, and suggests that the commissioners may have already experienced resistance to their demands, in Troyes or elsewhere. Alternatively, they may simply have wanted to collect the levy as quickly as possible so that they could move on.

By 10 o'clock on the Sunday morning popular agitation had begun in the streets. Doubtless keen to prevent the trouble from escalating and apparently sympathetic with the protestors' grievances if not with their means of remedying them, Nicolas Dare and his fellow-échevin Louis de Villeprouvée, accompanied by the royal prévôt, Nicolas Jaquot, went to remonstrate with the commissioners over the size of the levy which appeared much inflated since the original demand. They reasoned that the people were impoverished because of the high price of grain during the last year, that there was a shortage of work for local craftsmen, and thus great resentment was felt towards this further imposition on their meagre resources. The commissioners were advised to leave for their own safety; just one of their number was to remain to approach the crafts one-by-one with the authority of the city magistrate. Nevertheless, despite the officials' advice, the commissioners were not to be so easily deterred at this stage and declared that they were well able to defend themselves with the firearms they had to hand. Having tried in vain to defuse the situation and avoid a confrontation, the officials withdrew and left the royal representatives to face the wrath of the people.

After vespers a crowd began to assemble outside the commissioners' lodgings in the rue de Croncels, and by 7 o'clock there were said to be nearly 800 poor people, men, women and children, gathered outside. The local officials attempted once again to intervene and disperse the crowd, but were themselves forced to retreat as the numbers grew. The protestors then broke into the lodging, seized and beat one of the bailiffs who, in order to save his life, revealed the names of those who had been responsible for summoning ('qui les avoient faict venir') the commissioners to Troyes. ${ }^{12}$ He was then dragged to the house of one of those he had betrayed Raguin, clerk of the district or bailliage - and was murdered; the house was pillaged and papers found within were burned. At this point the local militia broke up the riot.

At midnight, the remaining commissioners, now rather less defiant, were escorted by the militia out of the city gate of La Madeleine to a place of safety nearby. However, calm was only briefly restored. By 4 o'clock in the morning the people were reconvening with the intention of attacking

11 Dare, 49-50.

12 Beik, Urban Protest, 55, refers to these men as 'local financial backers', but Dare, 51, is much vaguer about their connections with the tax-collectors. Pierre de L'Estoile, Registre-journal du règne de Henri III, ed. Madeleine Lazard and Gilbert Schrenck, vol. V (1585-87) (Geneva, 2001), 190, simply states that they were 'mixed up' with them: 'qui se mêlaient de telles maletôtes'. 
the houses of the other collaborators named by the murdered bailiff. This time the local militia refused to act to defend the tax-collectors and the properties were duly pillaged. It was then that a self-styled leader of the revolt emerged, a poor weaver who was reported to have said, 'We need a captain; if you want it to be me look at what I am carrying on my shoulder; it is a fork, call me Captain Fork. ${ }^{13}$ Hostile commentators claimed that most of those who followed the captain were children (enfans) aged between 7 and 15, armed only with stones. ${ }^{14}$ Yet, from this unpropitious beginning, Captain Fork's band was to prove more of a threat to civic order than any of the unrest that had gone before.

The protestors now turned their attention to several rich citizens' houses in the vicinity. Although initially driven away by the neighbours of most of those they had targeted, the rioters faced no opposition in breaking into and pillaging the house of Nicolas Largentier, merchant and captain of the district militia. Whatever the reasons for the failure to defend his residence, it was a potentially dangerous development since the house acted as a munition store for the city containing, it was claimed, enough weapons and ammunition to arm 500 men, and was located not far from the Croncels gate which housed the royal gunpowder store. Whether as a result of the increasing volatility of the situation or the emerging threat to civic security, the authorities now took more concerted action to quell the unrest.

The revolt was finally ended by the intervention of 200 armed bourgeois under the command of two local officials, in lieu of the reluctant regular militia. 2 of the rioters were killed on the spot and 80 injured, 30 of whom died within the next few days. In the afternoon, the officials carried out a search of the poorer inhabitants, making a further 32 arrests and recovering most of Largentier's property. Next day, Tuesday 1 July, the royal representative in the province, Lieutenant-Governor Dinteville, arrived with his entourage having been informed of the sedition. By his order, on the Wednesday night, Captain Fork and his wife and two other leaders were arrested, and the following night hanged in the prisons, presumably to avoid reactivating the unrest as a public execution might have done, whilst a deterrent was provided by the displaying of the bodies on gallows outside the town. Most of the other prisoners were released, except five who were detained to await the royal will. From the first act of defiance to the arrest of the ringleaders, the revolt had lasted less than four days.

${ }^{13}$ Dare, 51: 'Il nous fault ung capitaine; si voulez que je le sois regardez que c'est que je porte sur mon espaulle; c'est une fourche, nommés moy le capitaine La Fourche.'

14 On the involvement of children in confrontations during the religious wars, see Crouzet, Les guerriers de dieu, vol. I, 76-91; Davis, Society and Culture in Early Modern France, 1834; Wolfgang Kaiser, Marseille au temps des troubles, 1559-1596 (Paris, 1992), 202-4; and specifically on Troyes, Penny Roberts, A City in Conflict: Troyes during the French Wars of Religion (Manchester, 1996), 46 and 85. 
However, this was not to be the end of the demonstrations of discontent in Troyes that summer. Two months later, at the end of August, there was a further outbreak of unrest, led by textileworkers (mostly shearers or tondeurs) against a surcharge levied per pound of bread which they confusingly claimed was pushing up the price of wheat and rye. ${ }^{15}$ Despite the mayor's acceptance of their petition, the protestors proceeded to threaten the houses where they believed grain was being hoarded, principally those of corn-merchants and tax-collectors. In order to calm them down, the authorities took them into several virtually empty granaries, but they were still not appeased and demanded that corn be sold at less than half the current value or they would break in and seize it.

The next day a group of 40-50 journeymen gathered, armed with stones and daggers, but the night watch intervened. The following night the protestors waited until the watch had retired at 2 a.m., and proceeded to pillage the houses of several rich citizens, including once again that of Nicolas Largentier, which had been barricaded since the June revolt, and of former mayor Louis Le Mairat. However, this time, perhaps because of the escalation in violence against private property or of the royal reprimand they had received after the previous unrest, the authorities were swifter to act. Lieutenant-Governor Dinteville and his men arrived that evening, and eleven suspects were seized in their beds overnight. Six days later they were brought to trial, but were banished rather than executed, Dare alleges, because the judges had been threatened and may have lost their nerve at this juncture. In general, this episode appears to have rapidly acquired a more menacing air; Dare describes it as 'this pernicious and dangerous conspiracy'. ${ }^{16}$ Nevertheless, he also highlights once again the problems which the journeymen faced: that they had been forced to pledge their possessions because of the expense of grain compounded with a poor grape harvest.

Thus, whilst the motives and demands of the two outbursts of discontent were different, the underlying socio-economic difficulties which they revealed were the same. Like wage-earners throughout Europe at this time, the craftsmen of Troyes faced a decline in the real value of their wages at a time of inflation, underemployment and increasing numbers reliant on poor relief. The population pressure which underlay these trends also made the outcome of each harvest more crucial, and periodic epidemics hit the undernourished population hard. The French religious wars of the 1560s to 1590s worsened the situation still further, resulting in a disruption of trade, agricultural devastation and heavy royal taxation. The decades of the 1580s and 1590s were particularly tough in northern France, but this picture of popular immiseration and building social tensions holds good for southern French towns too, such as Marseille, which also experienced

15 On the August protest, see Dare, 59-62, and on this specific point: 'oster les cuisences du pain à la livre, disans qu'il(s) mettoient la cherté au bled, seigle nouvel', 59 .

16 Dare, 61: 'ceste pernicieuse et dangereuse conpiration'. 
unrest. ${ }^{17}$ The intensification of military activity in Champagne, following Guise attempts in 1584-85 to capture strategic centres in the region including Troyes, placed the city on a state of alert. In 1585, LieutenantGovernor Dinteville introduced a set of new regulations for municipal defence. ${ }^{18}$ However, urgent repairs to the city's fortifications were needed, and Dinteville suggested that the expense of these might be covered by the crown foregoing a levy of 4,000 écus, so that the reconstruction of Troyes would serve as an 'example to others'. ${ }^{19}$

In October 1585, the authorities in Troyes reported shortages in grain supplies to the provincial governor, the duke of Guise. ${ }^{20}$ The months immediately preceding the revolts also witnessed the escalation of the subsistence crisis in Champagne. Heavy rain ruined the grape harvest which, in turn, inflated the price of wine; other crops also suffered and restrictions were placed on the quantity of grain purchased and passports required to take it out of the city. ${ }^{21}$ One source refers to the containment of disturbances by the people roundabout the town at the end of July, between the revolts, because of the shortage of wheat and resulting famine; a rare reference to a rural dimension to the unrest. $^{22}$ One measure of urban concern over the fluctuating grain prices was the decision to change the form of assessment of contributions to poor relief from loaves of bread to money, which may have been a further source of antagonism to the participants in the revolts. ${ }^{23}$ The outbreak of one of the most serious plagues of the century in northern France was further disruptive to livelihoods dependent on raw materials imported from, and goods exported, elsewhere. Despite the authorities' attempts to alleviate these problems following the revolts - by doubling the contributions to assist victims of the plague, organizing the sale of alternative grains to wheat and the provision of work for the unemployed, as well as pleading against the imposition of a further 'loan' to the crown - the hardship and resulting tension remained. ${ }^{24} \mathrm{~A}$ few months after the revolts, the municipal authorities appealed to the duke of Guise again regarding the need to

17 Philip Benedict, 'Civil war and natural disaster in northern France', in P. Clark (ed.), The European Crisis of the 1590s (London, 1985), 84-105; Finley-Croswhite, Henry IV and the Towns, 14-17; Kaiser, Marseille, esp. 249-57.

18 BN, Fonds Dupuy, MS 228, fos. 162-77: 'Règlement pour le garde et guet de Troyes'.

19 'Lettres de Monsieur de Dinteville, 1585-87', Revue de Champagne et de Brie, 13 (1882), 61-2, 21 Mar. 1585: 'et sert de miroir et d'exemple aux autres'.

20 Archives Municipales de Troyes (hereafter AM Troyes), Fonds Boutiot, AA 31, liasse 1 (Blés, grains - approvisionnement et commerce, 1552-1789).

21 Dare, 40 and 45; 'Extraits d'un registre domestique de Jean Bonjour Le Jeune, notaireès-foires de Champagne à Troyes (1531-86)', ed. C. de Breban, Annuaire de l'Aube (1840) (hereafter Bonjour), 65.

22 AM Troyes, Fonds Boutiot, AA 31, liasse 1, 3 Aug. 1586.

23 Dare, 47. AM Troyes, Fonds Boutiot, AA 35, liasse 1 (Aumône générale, 1536-1614).

24 AM Troyes, Fonds Boutiot, A 22, register of town council deliberations, 29 Aug. 1586; AA 31, liasses 1 and 5 (Vagabonds, belistres, mendicans, 1532-1700); AA 35, liasse 1; AA 37, liasse 1 (Epidemies, maladies contagieuses, pestes, 1509-1722). 'Lettres de Monsieur de Dinteville', 62 . 
provide grain to feed the people and to prevent the spread of a virulent illness which had already struck down many, both rich and poor, on top of which the debasement of the coinage 'angers the poor people because of their necessity and poverty'. ${ }^{25}$

The nature of the grievances, the initial provocation, the actions of the participants, the reaction of the authorities and the outcome of the revolts in Troyes, all follow a familiar pattern. Furthermore, the trends against which the discontented were reacting in 1586 - increases in royal expenditure, indirect taxes and high grain prices - would continue to cause unrest in Troyes and elsewhere well into the seventeenth century. ${ }^{26}$ However, the peculiar circumstances of the wars undoubtedly exacerbated the economic difficulties faced by the protestors, just as political struggles coloured the authorities' attitude towards demonstrations of popular discontent. The citizens of Troyes had good and well-established reasons for feeling aggrieved with the direction of royal policy by 1586 . Yet these grievances were primarily socio-economic rather than political.

In the towns, it was the craftsmen who bore the burden of the sharp increase in royal taxes between 1576 and 1590. They were also hardest hit by surcharges on wine, grain, flour and salt, impositions resisted in 1578-79 by the estates of the northern provinces of Brittany, Burgundy, Champagne, Normandy and Picardy. ${ }^{27}$ The introduction of a further imposition in the 1580 s, and one that was clearly unconnected with the financing of the war effort, in addition to the high-handed manner of its implementation, aroused indignation which was the culmination of a long and growing list of grievances. The warning signs were already present the previous year, when Dinteville wrote to the king that a recent royal fiscal demand would stir up the craftsmen and, 'since they form more than three quarters of the town's population, they will drag the rest where their fancy takes them without remedy'. ${ }^{28}$ The workers of Troyes had not felt the need to protest with such force since the unemployment crises of the 1520s, when as a result of plague the council had prohibited the import of wool and linen with disastrous results for the drapers and paper manufacturers, consequently causing the discontent of thousands of workers. ${ }^{29}$ In 1586 they may also have seized the opportunity offered by the absence on business of all but three of the top city officials to give vent to their frustrations.

25 AM Troyes, Fonds Boutiot, AA 31, liasse 1, 28 Oct. 1586.

26 On the 1620s, Beik, Urban Protest, 85-91, and B. Porchnev, Les soulèvements populaires en France de 1623 à 1648 (Paris, 1963), 133 and 265; also see J.H.M. Salmon, Society in Crisis: France in the Sixteenth Century (London, 1975), 312, on riots in 1596. Finley-Croswhite, Henry IV and the Towns, 146-61, and Farr, Hands of Honor, 201-10, examine other early seventeenth-century French urban revolts.

27 Farr, Hands of Honor, 201-22. BN, Fonds Dupuy, MS 87, fos. 39-43.

28 'Lettres de Monsieur de Dinteville', 61: 'comme ils forment plus des trois quarts de la population de la ville, ils entraineroient le reste où la fantaisie les pousseroit sans pouvoir d'y remedier'.

29 Heller, Iron and Blood, 28. 
The streets of the quarter of Croncels in which the protest took place housed the richest inhabitants of that particular district of the city, principally merchants living in or around the rue du Temple. In contrast, a quarter of the area's householders were classed as too poor to pay tax. The predominant occupational group was the textileworkers, constituting one third of the district's inhabitants, including over half of the city's shearers and dyers (shearers having led the second revolt). But more proportionately significant were the leatherworkers, representing a quarter of the population rather than an eighth as they did in the city as a whole, in particular the tanners. ${ }^{30}$ This grouping of dyers and tanners is explained by the plentiful supply of water available in this area of the city, the result of the rerouting of the Seine through the town in the twelfth century. ${ }^{31}$ The leatherworkers, in particular, were restricted by the unpleasant odours resulting from their work, which caused the authorities to designate a separate zone for them which became known as the Tanneries. This group was further singled out by the authorities in the plague regulations for 1586, because of the risk of disease being carried on the animal hides with which they worked, and which they were consequently forbidden to bring into the town. ${ }^{32}$ Such a measure may well have further threatened their livelihood at an already difficult time, whilst the mastership tax may have seemed like the last straw, especially when access to masterships was being increasingly restricted by the existing masters, who were responsible for the regulation of their particular craft group in line with Troyes' status as a ville jurée. It was this status, more common than that of a ville libre such as Lyons (free of guild statutes and the domination of the masters), which made the town's population liable for the levy which triggered the June revolt. ${ }^{33}$

It is tempting to speculate that ultimately the unrest reflected antagonism between the poorer and richer inhabitants of the quarter in which it took place, but because of the lack of surviving trial records it is impossible to establish exactly who was involved. Thus it cannot be shown, as for some other revolts, what degree of preplanning and organization lay behind the protest, and whether it respected parish or quarter boundaries. It may be that the inhabitants of this area received the brunt of the commissioners' aggression in demanding the payment because of its proximity to where they were lodged. On the other hand it would have been easy enough

${ }^{30}$ On these calculations for Croncels, see Roberts, A City in Conflict, 22 and Appendix 1, 197-9. During a search of the district following the June revolt, inhabitants complained that the main street by the river had been 'incommodez' for about two years: AM Troyes, Fonds Boutiot, A 22, 12 July.

31 E. Chapin, Les villes de foires de Champagne, Bibliothèque de l'école des hautes études, no. 268 (Paris, 1937), 34 and 241-2.

32 AM Troyes, Fonds Boutiot, AA 37, liasse 1.

33 Farr, Hands of Honor, 16-17, 47-55, on the significance and evolution of juré and libre status. 
for the discontented from the rest of the city to gather there. ${ }^{34}$ The fact that the same wealthy individuals' houses were targeted in both the June and August revolts suggests a degree of organization and co-ordination, especially in view of the opportunity to arm themselves presented by the weapons-store kept chez Nicolas Largentier, as too does the regrouping of the protestors when the watch came off duty.

The surviving accounts do not reveal whether the initial protest was divided along craft lines or which trades were most affected and thus had a vested interest in opposing the levy. ${ }^{35}$ Dare mentions the participation of many from the villages in the countryside roundabout Troyes, suggesting that the protest went beyond the initial provocation of the royal levy on urban craftsmen, therefore reflecting more established grievances. ${ }^{36}$ It may be that there was some rural appeal in pillaging some of the richer inhabitants of the city who owned estates in the countryside, but there is no evidence for attacks on rural estates such as happened around Marseille in 1578-79, Romans in 1580 and Agen in 1635. ${ }^{37}$ The elusive Captain Fork, of whom we know nothing beyond his occupation and his badge of office (as it were), his pitchfork, may have supplemented his income by working in the fields; arguably, though, it was an implement equally suited to urban use. What is clear is that poor artisans living in the city were the most active in the revolt, judging by the official round-up of prisoners and property from individual houses following the disturbances. On the whole, therefore, it seems that the participants in the revolt were typical of its kind: poorer citizens, journeymen, apprentices, servants - therefore drawn from among the younger element within society and one largely excluded from the local political power networks - as well as agricultural workers from the suburbs and perhaps beyond. ${ }^{38}$ Dare states that many of the participants came from nearby villages, and that none of them had any means with the exception of a baker. ${ }^{39}$ However, the authorities usually found it prudent to dismiss the discontented as ignorant and of little worth, as reflected eventually in their account to the royal representative to play down the seriousness of the unrest, stating notably that 'not a single

${ }^{34}$ Interestingly, this quarter of the town also saw much of the religious conflict of previous decades, although it must be stressed that, notably in terms of participants, there appears to be no other link to these earlier troubles. Cf. Roberts, A City in Conflict, 78 and 82.

${ }^{35}$ However, a record of the amounts to be levied does survive, dated 14 Dec. 1585, although it may bear little relation to those eventually demanded. It is nonetheless interesting in the way it divides the crafts into 'les meilleurs', 'les mediocres' and 'les plus petits'. Notably, tanners, shoemakers and other leatherworkers were placed in the top category and therefore commanded the highest levy of 20 écus. See BN, Imprimés, F 46880, no. 29.

${ }^{36}$ Dare, 54.

37 Kaiser, Marseille, 236-8; Le Roy Ladurie, Carnaval de Romans, 150, 170, 190-4, 360, 363; Beik, Urban Protest, 66.

38 Cf. Le Roy Ladurie, Carnaval de Romans, 27-31, regarding the social breakdown of participants; Pillorget, Mouvements insurrectionnels, 319; Finley-Croswhite, Henry IV and the Towns, 146.

39 Dare, 54: 'ung seul homme qui est aucun moien, si peu que ce soit'. 
master craftsman' was involved. ${ }^{40}$ Nevertheless, fears of social subversion also emerge from the accounts of the revolts. After the first, the royal président of the regional court, Eustache de Mesgrigny, declared that the union and welfare of the town was dependent on the maintenance of order by its officials and the people's obedience, and 'that each inhabitant should recognise his status' ${ }^{41}$ Official concerns were reinforced by rumours that poor craftsmen were heard to have muttered 'that it is necessary to share with the rich'. ${ }^{42}$ But such stories probably have as much to tell us about the paranoia of the authorities as the concerns of the people, as we will see.

Yet, as already indicated, the authorities were not without sympathy both for the plight of the workers and their grievances against the actions of the royal tax-collectors, and they were also well aware of the impending subsistence crisis which the region faced. Even the échevins thought the high price set on the masterships, said to be six times that of the original charge, excessive. It is evident, too, that in anti-fiscal revolts there was some consensus that the kind of social climber who had bought his way into office that the commissioners were perceived to represent, was benefiting from ill-gotten gains, lining his own pockets at the expense not only of the people, but also of the king. ${ }^{43}$ Such a perception could result in an alliance of the people and the authorities against the outsider and his interference in local affairs, such as the raising of taxes. ${ }^{44}$ We see this, for example, in the expectation that if local officials accompanied the royal agents then the craftsmen, used to being policed by the municipality, were more likely to comply. Thus the protestors also turned their attention to those perceived as traitors to the community for fraternizing with, and inviting in, the tax-collectors. An extension of this was to go against those seen as part of a wider evil, those whose social status or occupation involved profiting from the people's misery, in the minds of the protestors tarred with the same brush as the gabeleurs (excisemen) or maltôtiers (extortioners), as they were commonly known; Beik's 'culture of retribution'.$^{45}$ The widespread hostility to such individuals is reflected in the attitude of the local militia who refused to protect them; a reluctance to act also shared by the authorities. For example, Nicolas Largentier (a notorious local tax farmer as it turns out), owner of salt granaries and involved in other surcharges

40 AM Troyes, Fonds Boutiot, A 22, 12 July 1586: 'ny ung seul maistre des mestiers'.

41 Ibid.: 'il estoyt besoing que chacun des habitans recognût sa qualité'; interestingly, the president's house seems to have been one of those targeted in the June revolt and he was married to one of the daughters of Louis Le Mairat.

42 Dare, 61: 'qu'il falloit fere partage avec les riches'. Cf. Farr, Hands of Honor, on similar sentiments in Dijon in 1630, 209-10.

43 Bercé, History of Peasant Revolts, 344-5.

44 The Actes royaux also reveal that the crown had attempted on several occasions to make the local authorities responsible for collecting the levy, evidently to no avail, suggesting a further angle to the authorities' reaction to this intervention, e.g. see BN, Imprimés, F 46880, nos. 29 and 31 (Dec. 1585), and F 46881, no. 31 (Mar. 1586).

45 Bercé, Histoire des croquants, vol. II, 581-2; Porchnev, Soulèvements populaires, 267-8. 
on wine and cloth, found that even his neighbours and servants were not prepared to take any action to defend his house. Furthermore, his attempts to clear his name of any association with malletostes, and his pleas for compensation following the pillaging of his property in both revolts, received scant sympathy from the municipal authorities who were more interested in reprimanding him for allowing access to the munitions stored in his house. ${ }^{46}$ It was only following the direct intervention of the king that the issue of restitution from those responsible for the unrest was properly addressed. ${ }^{47}$

Too great a solidarity against agents of the crown could lead to royal suspicions that the local authorities had turned a blind eye to, if not openly encouraged, rebellion. This was especially true at a time when the king was politically vulnerable, and the circumstances of the wars rendered the continuing loyalty of a city like Troyes, strategically placed on the country's eastern frontier, vital. The tardiness or inefficiency of the municipal authorities in suppressing popular revolt was therefore seen by the crown as a deliberate act of connivance. There are plenty of instances of other major towns, or whole regions, in France being punished fiscally or otherwise for their insubordination, even at a less sensitively charged time. Following the revolt in Guyenne in 1548, Bordeaux's privileges were abolished, discontent against a sales tax in Limoges in 1602 led to the reduction of the powers of the consulate, and protests in Dijon in 1630 resulted in a stiff reprimand and hefty indemnity for the city. ${ }^{48}$ In 1586 the municipal authorities in Troyes had to work hard in order to convince the royal authorities that their slow response was not due to a lack of zeal on their part, but to the cold feet of the militia; even so the city was fined 1,500 écus. ${ }^{49}$ Although the king acknowledged that the local officials had behaved 'worthily' ('dignement'), he felt that they had neither acted quickly nor forcefully enough in suppressing the revolt which, he pointed out, was only satisfactorily achieved by the eventual arrival of his representative, Lieutenant-Governor Dinteville. ${ }^{50}$ Indeed, it is difficult to assess, since the main account we have of the revolt is written by one of the officials themselves, just how active the authorities may have been behind the scenes in fomenting discontent, but there is nothing to suggest that

46 AM Troyes, Fonds Boutiot, A 22, procès-verbal of Largentier, 8 July: that he had 'oncques meslé de subsides de malletostes, ny aucunement manier en toutes ses actions ains tousjours modestement et en homme de bien ayant faire service et plaisir au public ... ny fait chose contre l'autorité du Roy'. Dare, 61 and n. 1. Beik, Urban Protest, 55-6 and n. 10, discusses Largentier's reputation and financial connections.

47 BN, MS fr. 17990, fo. 108, 10 July.

48 On Guyenne, see Zagorin, Rebels and Rulers, vol. I, 239, and Salmon, Society in Crisis, 37. On Limoges, Annette Finley-Croswhite, 'Absolutism and municipal autonomy: Henry IV and the 1602 Pancarte Revolt in Limoges', in Mack P. Holt (ed.), Society and Institutions in Early Modern France (Athens, GA, and London, 1991), 80-97. On Dijon, Farr, Hands of Honor, 206-7.

${ }^{49}$ Dare, 61.

50 BN, MS fr. 17990, fo. 108, 10 July; Fonds Dupuy, MS 228, fos. 235-6, 22 and 24 July. 
they were. At the same time, however, it undoubtedly suited the crown to portray events in this manner.

Following the first revolt, steps were taken to inform both the king and the governor of the province, the duke of Guise, of what had happened and the measures that had been taken to prevent any recurrence, as well as to plead the case for rescinding the levy that had been the chief cause of the disturbances. ${ }^{51}$ Nicolas Dare was part of the municipal delegation on this occasion. On 5 July, the town council ordered local preachers and parish priests to admonish those who attended their sermons to remain quiet and refrain from any action which might rekindle the disturbances, suggesting that the situation remained tense. ${ }^{52}$ In the council session held a week later, Lieutenant-Governor Dinteville remarked that the greatest fault noted had been that its inhabitants had showed themselves so reluctant to obey the orders given to them by royal officials'. He urged that the notables of Troyes take heed in future of the most appropriate means by which they might deal with such disturbances and 'promptly extinguish the fire before it took hold' ${ }^{53}$ The mayor, who had been absent at the time of the revolt, blamed the local militia for failing to quell the unrest despite instruction from royal officials. The militia thus served as a scapegoat for the alleged negligence of the authorities, just as it would do under similar circumstances in the 1620s. ${ }^{54}$ However, Henry III, in a letter of 10 July, was furious at what he saw as a personal slight on his authority, declaring that he felt that the few deaths that had already occurred were insufficient for the gravity of the crime which had threatened 'to totally ruin one of the best towns in his kingdom'. ${ }^{55}$ Therefore, he ordered further trials and some exemplary executions to deter any further opposition, and directed that the rebels should provide compensation to those who had suffered at their hands. He also demanded that the findings of any investigations into the incident be reported directly to him in his council. In response, the town officials and Dinteville requested that the king forgo his demands for further retribution, since the people were now peaceful and it might serve

51 AM Troyes, Fonds Boutiot, A 22, 12 July 1586.

52 Ibid., 5 July 1586: 'admonester le peuple à leurs presches et predications qu'il ayt à se contenir sans bruit, ne commettre insolences ny s'esmouvoyr'.

53 Ibid., 12 July 1586: 'l'une des plus grandes faultes qui se fust remarquée avoyt esté de ce que les habitans d'icelle s'estoyent montrez fort froids à obeyr aux mandemens qui leurs avoyent esté faictz par les officiers du Roy ... qu'il estoit de besoing et à l'advenir y donner ordre et adviser sur les moyens propres que l'on debvroit tenir afin que tel inconvenient advenant on y puisse remedier sur le champ et promptement estaindre le feu avant qu'il fust embrasé'.

54 Beik, Urban Protest, 85-90, discusses the anti-fiscal revolts of 1625-26 in Troyes, during which the inaction of the local militia rendered the authorities impotent.

55 BN, MS fr. 17990, fo. 108, 10 July: 'mettre en totalle ruyne l'une des bonnes villes de son royaulme', using a combination of flattery and threat characteristic of royal responses to acts of disobedience, see Finley-Croswhite, Henry IV and the Towns, 9-10, 147-51. Cf. the view of Mark W. Konnert, Local Politics in the French Wars of Religion: The Towns of Champagne, the Duc de Guise, and the Catholic League, 1560-95 (Aldershot, 2006), 187-9, who sees Henry III's heavy-handed approach on this occasion as alienating royal support. 
to reignite rather than to deter further trouble. Henry relented, in a further letter of 22 July, on condition that they continued their exhortations to the people to remain quiet and obedient and refrain from further insolence towards their sovereign: 'that the ill advised among their fellow citizens take care never to return to the same faults, but to always show due reverence and obedience to our commands' ${ }^{56}$

Nevertheless, it still seems curious that the unrest, that was after all small scale, short lived and swiftly crushed, received such attention at court. The king clearly took the incident very personally indeed, but his anger went well beyond the snub of a gift to his sister, for at that time he had no less than 27 fiscal edicts before the Paris Parlement. These had already aroused vociferous protests in the capital, and it would not have aided his cause, nor improved his humour, to receive news of opposition to an existing levy. ${ }^{57}$ It was also the case that this demand had first been made over six years before, with the legislation intensifying month by month from December 1585 , revealing the extent of royal frustration with trying to enforce the tax. When coercion and commands to mastercraftsmen and local authorities to take charge failed to produce a result, an extraordinary commission was brought in, never a popular move. ${ }^{58}$ In addition, this was the reaction of a monarch who felt politically weak and exposed, especially when faced with dissent in one of the major cities susceptible to League influence, since the duke of Guise was governor of Champagne. From the crown's point of view such disturbances, which could be construed as overt opposition to the royal will, took on a more sinister aspect at a time of organized anti-royal activity. Nevertheless, the king's handling of the situation was perfectly in keeping with that of his predecessors and successors who, when faced with urban dissent, 'tended to operate between the poles of paternalistic forgiveness and vengeful chastisement'. ${ }^{59}$

Nor was the reaction in the capital confined to a vigorous royal response. The journal of a Parisian resident, Pierre de L'Estoile, reports the incident (notable principally, according to him, for the excessive force used by the commissioners) alongside other similar outbursts of popular discontent at the increasing burden of royal taxation. ${ }^{60}$ Some historians have seen

56 AM Troyes, Fonds Boutiot, A 22, 5, 8 and 12 July; AA 31, liasse 1, 3 Aug. BN, MS fr. 17990, fo. 108, 10 July; Fonds Dupuy, MS 228, fo. 235r, 22 July: 'que les maladvisez de leurs concitoyens se preignent garde de ne tomber jamais en semblables faultes, ains de porter tousjours la reverance et obeyssance qu'ilz doibvent a noz commandemens'.

57 Dare, 56. R.J. Knecht, The Rise and Fall of Renaissance France (London, 1996), 518.

58 See Actes royaux, BN, Imprimés, F 46880, nos. 29 and 31, F 46881, nos. 9 (9 Jan., commission to levy by constraint), 17 (12 Feb., announced that it was 'expressement deffendu à toutes personnes de troubler \& empescher à l'execution desdites commissions \& contrainctes'), and 31 (19 Mar., 'ce à cause des intelligences qui sont entre noz juges et officiers, avec les habitans des villes s'il ne leur est plus estroictement enjoint $t^{\prime}$ assister').

59 Finley-Croswhite, Henry IV and the Towns, 147.

${ }^{60}$ Registre-journal, vol. V, 190. In an otherwise well-informed account, L'Estoile incorrectly cites 'un argentier' (a silversmith) in place of Largentier. On other contemporary revolts in Beauvais and Normandy, see Crouzet, Les guerriers de dieu, vol. II, 267 and nn. 125-6 $(280-1)$. 
these anti-fiscal revolts of the 1580s and 1590s in terms of recruitment to the Catholic League and thus in opposition to the kingship of Henry III, a view which would confirm the fears of the crown. It is suggested that the League manipulated public opinion by taking advantage of the people's grievances and hardship to undermine the position of the monarchy and to enhance their own support. ${ }^{61}$ Yet this is too simplistic a picture of the workings of sixteenth-century urban politics at a provincial level, which involved the defence of local interests against the fiscal demands of the crown whatever the allegiance of the individual, as demonstrated by the actions of the unwaveringly Royalist Dinteville, in response to impending subsistence crisis in both 1585 and $1587 .{ }^{62}$ However, the crown feared that popular protests, particularly those aimed against aspects of royal policy, were indicative of a groundswell of support for the League. Nevertheless, League leaders no more than municipal authorities could rely on social unrest working to their advantage; the outcomes were too unpredictable.

It is unclear whether the participants in the revolts of 1586, or those in general dissatisfied with exorbitant royal levies, were attracted by the League. It is notable that the tax farmer, Largentier, was among those excluded from office and then expelled from the city as a Royalist in 1589. Other targets of the protestors who would later prove to be ardent supporters of the crown included Louis Le Mairat, re-elected as mayor following Troyes' submission to Henry IV in 1594, and clerk Antoine de Vienne. Nevertheless, the property of staunch Leaguers was also attacked, notably the houses of Nicolas Domino and Nicolas Le Marguenat, later to sit on the local League council. Nor, indeed, would such allegiances necessarily have been so evident to the people at this stage. Those municipal officials responsible for dealing with the unrest were also split ideologically by the League coup in 1588: Nicolas Dare was himself to become a League councillor, whilst Nicolas Jaquot was arrested and expelled for being a Royalist. ${ }^{63}$ Dare certainly appears to have been sympathetic with the rebels' grievances, but he was no less eager than his Royalist colleagues to ingratiate himself with the crown following the disturbances; the time had not yet come for open defiance of the king.

Political allegiances at this point, then, remained uncertain. Doubtless some local officials felt unsettled by the suggestion of monarchical weakness and corruption contained in the League-sponsored political pamphletry to which they were increasingly exposed. Nor should we discount their apparent prevarication in the face of popular unrest,

${ }^{61}$ See, for example, Crouzet, Les guerriers de dieu, vol. II, 267; cf. Farr, Hands of Honor, 198. On both the problems of manipulating popular support and the role of the Guise faction in the 1580s, see Stuart Carroll, 'The Guise affinity and popular protest during the wars of religion', French History, 9 (1995), 125-52.

62 AM Troyes, Fonds Boutiot, AA 31, liasse 1, 28 Oct. 1586; 'Lettres de Monsieur de Dinteville', $61-2$.

63 On the League/Royalist divisions in Troyes, see Roberts, A City in Conflict, 173-83; and most recently, Konnert, Local Politics. 
which may suggest a degree of dissatisfaction with crown policy and a willingness to give a platform to discontent. Although the protestors, too, were susceptible to anti-regime propaganda at a time of crisis, just how this translated into action is more difficult to gauge. More significant may be the absence of a confessional dimension to the unrest, seen elsewhere as a direct link to sympathies with the League, despite Troyes' long history of conflict between the faiths. ${ }^{64}$ All the evidence suggests that for the participants in the revolts, economic concerns far outweighed the political and confessional struggles being waged at a national and local level, as indeed economic issues were foremost in the minds of the third estate in Troyes when the League sought to woo supporters to its cause in the 1570s. The deputies responded by setting down preconditions: the more even distribution of the fiscal burden, keeping down the cost of troops and ensuring that officials and captains fulfil their duties. ${ }^{65}$ Whatever game the authorities may have been playing in 1586 in their ambivalence over the justice of the protestors' cause, there were more reliable means by which both sides could gain or retain influence in Troyes than through winning popular support.

Both before and after the revolts, crown/League conflict was evident in the municipal politics of Troyes, with both sides exerting all means at their disposal, including bribery and the pulpit, to ensure the election of their own candidates to the principal offices of mayor and échevins. This was the case in both 1586 and 1587, when the king selected from a short-list submitted by the authorities. ${ }^{66}$ But from 1588 to 1594, when the League had control in Troyes, their supporters were elevated and pro-Royalist opponents expelled. The disloyalty of many of the principal French towns during this period of League ascendancy, a reflection of the still considerable potential of municipal autonomy to undermine royal authority, was a lesson not lost on the crown. It is not surprising, therefore, that once the crown was in a powerful enough position to do so in the seventeenth century, independent control of municipal defences and finances were curbed. ${ }^{67}$ Intervention in municipal elections to senior posts was also exploited, both to secure malleable local officials and as a means to raise revenue. The local authorities could still expect to be severely reprimanded, and suspicion cast on their loyalties, as a result of

64 The confessional element in other revolts is emphasized, for instance, by Finley-Croswhite, Henry IV and the Towns, 152-3, and Farr, Hands of Honor, 198; Le Roy Ladurie, Carnaval de Romans, 95-102. The confessional conflict in Troyes is explored extensively in Roberts, $A$ City in Conflict.

65 AM Troyes, Fonds Boutiot, BB 14, liasse 2, no. 62; BN, Fonds Dupuy, MS 87, fo. 99.

${ }^{66}$ Dare, 48-9 and 64-6; Bonjour, 66. Bibliothèque de l'Arsenal, Paris, MS 4254, fos. 149-50. The franchise was more limited in Troyes than, for instance, in Dijon, and the rigging of elections therefore involved less need to ingratiate candidates with the people.

${ }^{67}$ Nora Temple, 'The control and exploitation of French towns during the ancien regime', in R.F. Kierstead (ed.), State and Society in Seventeenth-Century France (New York, 1975), 67-93. On continuing interference in municipal elections under Henry IV, see Finley-Croswhite, 'Absolutism and municipal autonomy'. 
popular unrest within their jurisdiction, if it was deemed by the crown not to have been suppressed swiftly enough. By the same token, the crown took advantage of the opportunity provided by such events to reduce the independence of action of local officials, as well as to impose a hefty fine, a trend already well established in the sixteenth century. ${ }^{68}$

It is argued that it was under Henry II (1547-59) in the 1550s that urban autonomy was first seriously attacked by the crown, in the drive to finance the escalating costs of military ventures. However, since at least the mid-fifteenth century there had been efforts to retain the loyalties of the so-called bonnes villes by keeping a tight rein on those seen to be resisting royal policy. ${ }^{69}$ The peculiar circumstances of the religious wars of the mid- to late sixteenth century provided a further opportunity for towns to organize their own defences and administration in the provinces sometimes in defiance of the crown, and demonstrated to the monarchy the extent to which municipal autonomy could obstruct the extension of royal authority. Yet the period also witnessed the continuing dialogue between the crown and its municipal elites, with royal intervention in elections usually serving simply to uphold the local choice of candidate. ${ }^{70}$ At the same time, relations between municipal and royal authorities were peripheral to the grievances of the participants in the unrest in Troyes in 1586, who by their actions were continuing a tradition of revolt that had little to do with either struggles for power on a national level or local factional disputes. For them, of much more pressing concern was the imminent subsistence crisis compounded by increasing and seemingly arbitrary fiscal demands on their already overstretched resources. Neither royal nor League policies would succeed in easing these burdens, and the situation was far too volatile for either side to be confident of channelling this discontent for their own political purposes. Ultimately, only peace could bring the relief that the craftsmen of Troyes sought through revolt.

The significance of an incident such as the revolts in Troyes in the summer of 1586 reach far beyond the local tensions and grievances which provoked the discontent. On the one hand, it demonstrates the ability of townspeople to organize an effective protest which forced the authorities to take notice and to alter their approach accordingly. On the other, it underlines the continuing authority of the crown which could bring pressure to bear on, and make answerable, its representatives in the provincial towns of France. Whereas Hilary Bernstein contrasts the forceful conduct of Henry IV towards Poitiers with the apparently weak approach of his predecessor, Henry III, the reaction of the crown to events

${ }^{68}$ L. Bernard, 'French society and popular uprisings under Louis XIV', in Kierstead (ed.), State and Society, 157-79.

69 B. Chevalier, Les bonnes villes de France du XIVe au XVIe siècle (Paris, 1982), with Louis XI (1461-83), the first monarch to establish the right to elect a mayor from three candidates submitted by the municipality of Troyes, 204. D. Potter, A History of France, 1460-1560 (London, 1995), 156-63.

70 See Finley-Croswhite, Henry IV and the Towns, 7-10. 
in Troyes in 1586 suggests that an assertive stance was more customary at least prior to the royal nadir of $1588-89 .{ }^{71}$ It is certain that early modern urban politics involved negotiation and compromise, 'within the context of traditional power relations'. ${ }^{72}$ Equally, it is clear that mutual distrust and fear existed between social groups, placing strain on community solidarity. Whilst the collective expression of grievances could be seen as an accepted part of the political process for the disenfranchised, violence and threats to people and property were not. An overt challenge to royal policy, and therefore authority, was the least palatable of all and provoked a decisive response. Nevertheless, the popular voice could not be wholly ignored once it had spoken, and early modern municipal elites were sensitive to the balance that needed to be struck between the maintenance of order and the suppression of disorder. At the height of the religious wars this was an important lesson to be heeded by both sides, but one that was learned through a long tradition of urban protest and demonstration that would continue long after the national conflict was over.

${ }^{71}$ Bernstein, Crown and Community, 261. See on this point, Finley-Croswhite, Henry IV and the Towns, 1, 5, 182-6.

72 Beik, Urban Protest, 264. 